\title{
MOTHERHOOD, BREASTFEEDING AND ADOPTION: THE CASE OF HERA SUCKLING HERACLES
}

\begin{abstract}
Summary: Starting from some reflections on how Hera played the role of mother in mythological tales, we move to take into consideration the special case of the goddess suckling Heracles (sometimes as an adult). Notoriously, the Greeks attributed specific properties to breast-milk, such as transmitting genetic traits and creating bonds of kinship; therefore it does not seem unlikely to think that the episode in question alludes to the (symbolic) adoption by Hera of the illegitimate son of her husband, in order to let him access the divine family. Adoption in the ancient world, in fact, often involved adolescents and adults, with the primary goal being the provision of a legitimate heir to a citizen.
\end{abstract}

Key words: Hera, Heracles, breastfeeding, adoption, motherhood

Hera is usually considered simply as wife, but she also plays the role of mother, stepmother and nurse (or to say it better in the ancient Greek way, a kourotrophos). To be more precise, in her role as Zeus's spouse, she should not be simply considered as a wife, but as a queen: Zeus and Hera, in fact, share a complementary power, as Pirenne-Delforge and Pironti have clearly pointed out. ${ }^{1}$ As mother, the legitimate offspring of her union with Zeus are Ares, Hebe, Eris and Eileithyia. According to some versions, Hera was jealous of Zeus's giving birth to Athena without recourse to her, so she gave birth to Hephaestus without him, though in some stories he is the son of her and of Zeus. The goddess was then disgusted with Hephaestus's ugliness and threw him from Mount Olympus.

${ }^{1}$ Pirenne-Delforge-Pironti 2009, 95-109; Pirenne-Delforge-Pironti 2014, 27-31. According to them, Hera always has a key-role in case of legitimation issue, also gods like Athena and Dionysus need her "approval" to become part of the divine family, see PIRENNE-DELFORGE-PIRONTI 2015, 41-57. Nonnus (Dion. X 208-242) states that Dionysus will come selfsummoned into the heavens; he needs not Hera's milk, for he has milked a nobler breast (that of Rhea). 
Following a well-established tradition, in particular by putting emphasis on Hephaestus, Ares and Eris, Hera is said to be a terrible mother, who reared morally and physically ugly sons; somehow, an "anti-mother", who does not take care of her children and sometimes challenges them. But, if we try to extend this lectio facilior, we could take into consideration some interesting details, as I have tried to point out in a recent work, ${ }^{2}$ mythological tales involving Hera usually do not speak of maternity; the maternal/anti-maternal role they describe is therefore only a sort of "side effect" within other divine issues. Her motherhood/mothering changes enormously, depending on the context in which it is described. Usually it is not very relevant (such as, for instance, divine childhood). Her children are divine counterparts, are peers. They can be at time friends or enemies without big surprise. Consequently, we cannot state that her maternity was always a disaster, always something "negative". It really depends on what the story wants to tell, wants to teach, wants to transmit, wants to "establish". As Marianna Scapini also points out, it is functional to the myth.

Like other divine "colleagues" of hers, Hera has a kourotrophic role, which, in her case, is perhaps more evident if we take into consideration the cultural evidence, as we will see in the following papers. As Chiara Maria Marchetti point out in her Introduction on p. 338, if we take into account certain votives from Greece, a link with breastfeeding seems to be possible. Here I would like to focus on her relationship with Heracles. To him, she is a stepmother who can be at any time good or evil. Again, it depends on the specific situation. ${ }^{3}$

The controversial bond between Hera and Heracles begin even before the birth of the heros theos, ${ }^{4}$ and it always relates to a legitimacy and an inheritance issue.

Heracles was the son of the affair Zeus had with the mortal woman, Alcmene. One night Zeus disguised himself as her husband, Amphitryon, pretending to come home early from war (Amphitryon did return later the same night, and Alcmene became pregnant with his son at the same time). Heracles's twin mortal brother, son of Amphitryon, was Iphicles.

On the night the twins Heracles and Iphicles were to be born, Hera, knowing of her husband Zeus's adultery, persuaded Zeus to swear an oath that the child born that night to a member of the House of Perseus would become High King. Hera did this, knowing that while Heracles was to be born a descendant of Perseus, so too was Eurystheus, another of Zeus' descendent through Perseus still in his mother's womb. Once the oath was sworn, Hera hurried to Alcmene's dwelling and slowed the birth of the

${ }^{2}$ PEDRUCCI 2017a. In this regard, the following paper is extremely important: PIRONTI 2013, 155-167.

${ }^{3}$ We should point out this kind of ambiguity is usually typical of nurses in the ancient world: in fact, we have both the good and devoted nurse and the bad nurse, associated with the nocturnal bird strix (see n. 35). The stepmother is more often associated to a maleficent behaviour in ancient sources, at least as a stereotype. "The stereotypical stepmother encapsulates those qualities thought to be essentially feminine: emotional instability, lack of self-restraint, jealousy and treacherousness.": WATSON 1995, 128. For Hera as stepmother to all the younger divine generation, see BOISMENU 2009, 264: "Héra, épouse du maître, y est marâtre plutôt que mère, et règne sur tout ce qui est plus jeune qu'elle."

${ }^{4} \mathrm{Pi}$. N. III 22. This definition clearly shows Heracles's complexity, "che si muove liberamente in sfere tradizionalmente alternative", see BRILLANTE 1992, 199. For the ethymology of his name in connection with that of Hera, see LORAUX 1989, $138 \mathrm{ff}$. 
twins Heracles and Iphicles by forcing Eileithyia to sit cross-legged with her clothing tied in knots, thereby causing the twins to be trapped in the womb. Meanwhile, Hera caused Eurystheus to be born prematurely, making him High King in place of Heracles. Eurystheus himself would set Heracles's labours. ${ }^{5}$

Hera therefore does not attempt to eliminate the unborn child (by killing the mother, as in Dionysus's case), but only to delegitimize him. As noted by Silvia Romani, ${ }^{6}$ the difference is huge: the second "pregnancy" allows Dionysus to come into world on the day fixed by the Fates and, by springing directly from his father, he can legitimately be called the son of Zeus. But Hera, by contrast, by denying Heracles the right to be born on the day established for him, deprives him even before his birth of all his rights and condemns him to a destiny of labour.

Once born, the illegitimate Heracles is exposed by his mother (who has no longer any role in the story), terrified by Hera's revenge, and he is then abandoned to his mortal fate by his father, too. Athena, however, takes care of him: ${ }^{7}$ she plays an important role as protectress of heroes, as we said. In particular, she brings him to Hera. Hera does not recognize Heracles and nurses him out of pity. ${ }^{8}$ Heracles suckles so strongly that he causes Hera pain, and she pushes him away. Her milk sprayed across the heavens and forms there the Milky Way. His extraordinary destiny has begun. Heracles emerges victorious from each challenge and finally obtains what his father had promised him. After his death he became a god, but Zeus wanted also to make him his legitimate son, and unexpectedly it is precisely Hera who makes it possible. It is the goddess, in fact, who gives him her daughter Hebe in marriage. ${ }^{9}$ According to Diodorus, not only does she approve the marriage, but also mimes a scene of childbirth, ${ }^{10}$ as requested by her husband, Zeus. The simulation of childbirth, already interpreted by Diodorus as an adoption, would be necessary for Heracles's apotheosis. Indeed, Hera plays a key role in this story, but not as a persecutor (her typical role), but also as a (step)mother.

Although Silvia Romani ${ }^{11}$ mentions a very interesting series of similar cases, belonging to different periods, in which we can find some constants connected with legitimacy, a "mimetic" ceremony intended to build a fictitious biological bond by

\footnotetext{
${ }^{5}$ See: BetTini 1998, esp. 3-42; Romani 2004, 87-113. For Heracles's birth, see for instance Hom. Il. XIX 95ff.

${ }^{6}$ ROMANI 2004, 87ff.

${ }^{7}$ In Sch. Lyc. 39, Scheer II 31, Athena persuaded Hera to breastfeed the abandoned baby, but he suckled too hard and she got mad at him. In D. S. IV 9. 6, Athena found the abandoned child during a walk with Hera. Cf. D. S. III 70.2: Athena is said to be the phylax, that is the guardian of the child. In other variants it is Hermes to take care of little Heracles.

${ }^{8}$ D. S. IV 9. 6-7, points out the unexpected turn of events; for the mother, whose duty it was to love her own offspring, was trying to destroy it, while she who felt towards it a stepmother's hatred, in ignorance will saved the life of the very one (Heracles) who was her natural enemy.

${ }^{9}$ Apollod. II 7. 7. LorauX 1991, 137f. Cf. RomAni 2004, 87-113. For the importance of the wedding with Hebe, see infra.

${ }^{10}$ D. S. IV 39. 1-4: "Hera lay upon a bed, and drawing Heracles close to her body then let him fall through her garments to the ground, imitating in this way the actual birth; and this ceremony is observed to this day by the barbarians whenever they wish to adopt a son." (Translation by C. H. Oldfather, LCL 1967). See Romani 2004, 94-97. See also Sch. Lyc. 39, Scheer II 39.

${ }^{11}$ RoMANi 2004, 99-113.
} 
turning a bastard into a natural child through the simulation of the childbirth, apparently does not exist in the Greek world. Diodorus informs us that it is a barbarian practice, ${ }^{12}$ Plutarch (Greek and Roman questions, 265A) describes a similar ceremony, but one that is intended for those who, after an apparent death, must be reintegrated into

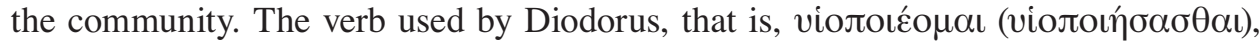
is rare and late, and, apart from a few isolated cases, not used to indicate adoption. ${ }^{13}$ Indeed, it gives a very concrete idea of the child's "creation". In patrology texts, however, it is used to indicate baptism. ${ }^{14}$ According to Silvia Romani, the theme of rebirth, as a means of passage to a new life and integration into a new social context, would be very consistent.

As we said, in some mythological versions the "simulated birth" is combined with another element ascribable to maternity, that is breastfeeding (Sch. Lyc. 39, Scheer II 31). To be more precise, breastfeeding is the key element in the formation of the Milky Way. The most ancient literary sources, which do not date back beyond the $4^{\text {th }}$ century BC, ${ }^{15}$ put this event in Heracles' early childhood and some of them stress the unawareness, sometimes even the anger, of Hera. The same theme can be found in the archaeological sources, but they are rather late and exclusively from ancient Italy, especially Etruria, where we can also find the representation of a bearded Heracles. ${ }^{16}$ On an Etruscan mirror, we find the inscription that is translated, "this shows how the mortal Heracles became Uni's legitimate son". We have to add a possible fresco in the Domus Aurea, according to scholars from the $18^{\text {th }}$ century. Some modern scholars suggest that there was an adult Heracles in the original version. However, this is a very unusual image, which should be probably located after the death of the hero, already integrated into the Olympian family through breastfeeding (that, in this case, has to be considered merely symbolic, of course). According to Nicole Loraux, it is a symbolic act of adoption, like the childbirth simulation described by Diodorus. There is, however, a big difference between the Greek documentation (exclusively literary) and the

\footnotetext{
${ }^{12}$ It is worth noting that this practise is labelled as barbarian, like the couvade and sometimes the act of breastfeeding. Cf. PEDRUCCI 2013a, 218, 301-306.

${ }^{13}$ Cf. RUdHARDT 1962, 39-64. 53ff. BRILlanTE 1992, 202, quotes an hymn in which Heracles is Zeus and Hera's son.

${ }^{14}$ For both classical and Christian sources in detail, see ROMANI 2004, 94-99.

${ }^{15}$ D. S. IV 9. 6; Paus. IX 25. 2; Lyc. Alex. 1327; Eratosth. Cat. XLIV 3-15 (it is not possible for Zeus's sons to be part of the honours of the sky without being breastfed by Hera); Hyg. Astr. II 43; Ach. Tat. Introd. in Aratum XXIV (cf. Sch. Arat. 474 Maas); Geoponica IA 19. See also AP IX 589 (see infra). For Hera as a stepmother, see PEDRUCCI 2013a, 104, n. 413. It is worth noting that, according to the Roman law, the wife of the adopter does not become the mother of the adoptee, but his stepmother (noverca), cf. CORBIER 2000, 17. She seems to be particularly evil in case of sons which Zeus had with mortal women, see PiRENNE-DELFORGE-PIRONTI 2009, 55.

${ }^{16}$ The first attestation of this motif is on a red-figured Lucan lekythos (middle $4^{\text {th }}$ century BC): in this case, Heracles is a child. Then, we have four Etruscan mirrors: on three of them Heracles is represented as a young boy, on one he is bearded (middle $4^{\text {th }}$ century BC); and a Faliscan crater $\left(4^{\text {th }}\right.$ century BC) with Heracles as a young boy. On one of the Etruscan mirrors, there is an explanation: this shows how the mortal Heracles has become the legitimate son of Uni, see: PIRENNE-DELFORGE 2010, 691ff., esp. n. 25. Cf. DEONNA 1954, 150-155; RENARD 1964, 611-618; HADZISTELIOU PRICE 1978, 192; BonfANTE 1989a, 89; BonfANTE 1989b, 180; PiRENNE-DELFORGE-PIRONTI 2009.
} 
Etruscan-Italic one (only iconographic) as the way to describe the same, controversial subject. The Latin culture, indeed, knew (and represented) other famous episodes of breastfeeding of an adult male, even with an explicit allusion to incest. ${ }^{17}$ Greek culture perhaps knew this story, but, at least according to the documentation in our possession, did not represent it. Maybe it is not a coincidence that the version including breastfeeding was exclusively represented in ancient Italy, where, probably because of a different sensitivity and different customs, scenes of breastfeeding were not unusual in the local art. On the contrary, in Greece they preferred the episode of the marriage with Hebe to justify Heracles's admission to the divine family.

In Pirenne-Deforge's opinion, the breastfeeding of Heracles by Hera and the marriage with Hebe, the Youth, should be read together. In fact, Hebe, being the Youth, can represent the arrival point of the "path" assigned to the nurse in the ancient societies: from childhood to puberty. In this way, the role of Hera as trophos, more specifically as "companion of heroes" would clearly emerge: the two episodes, Hera's breastfeeding and giving Hebe in marriage to Heracles, would represent, in short, two sides of the same coin. ${ }^{18}$

Personally, I would place particular emphasis on breastfeeding as a means to create kinships. In fact, we must always keep in mind breast-milk's proprieties: according to the ancients: breastmilk, being blood, was a vehicle of values, vigour and moral principles being siphoned into the baby's body-mind, in addition to the genetic characteristics it passed on. ${ }^{19}$

It is also worth noting that, in the Alexandra by Lycophron, we have the explicit mention of an "adoptive" relationship between Hera and Heracles. Hera, struck by

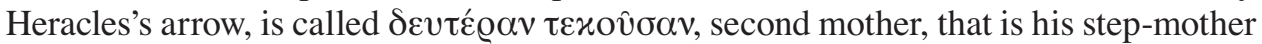
(the episode is already present in Homer). ${ }^{20}$ Subsequently, she is defined, in relation to

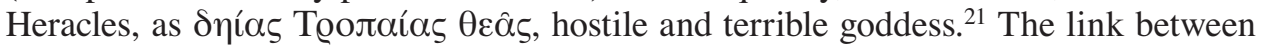
breastfeeding and the role of the stepmother/wet-nurse is present in an epigram of the Palatine Anthology (IX 589): the figure of the stepmother is distinguished from that of the mother, or at least from that of good nurse, precisely as concerns breastfeeding: her breast does not have milk, it is $\mu \alpha \zeta$ òv vó $\theta \mathrm{ov}$, bastard breast, or, rather, her milk is for a child other than a natural one (as in the case of Heracles and Hera). In this case, the breast for the bastards is empty, the nourishment is denied.

Unfortunately, we cannot find direct confirmation of what we have argued so far, as we know very little about the Greek practice of adoption: the sources we have are almost exclusively Attic orations that focus on hereditary issues and do not describe the "concrete" procedures of adoption (procedures for which there were no standard

\footnotetext{
${ }^{17}$ That is the story of Pero and Micon, see PEDRUCCI 2013a, 174, n. 61 (with previous bibliography). See also PEDRUCCI 2017b.

18 Pirenne-Delforge 2010, 694f. See also CApomaCchia 1994, 11-24; Brillante 1992, $219 f$.

${ }^{19}$ DANESE 1997, 39-72; PEDRUCCI 2013a; PEDRUCCI 2013b, 260-291. For the milk kinship, see MENCACCI 1996, 93, nn. 91f.; DASEN 2012, 48ff.

${ }^{20}$ Hom. Il. V 392f.; Lyc. Alex. 39. Cf. BRIllante 1992, 215.

${ }^{21}$ Lyc. Alex. 1326f. See also Photius, Bibl. 190, 38-40 (148a), in which Heracles is called the son of Hera and Zeus.
} 


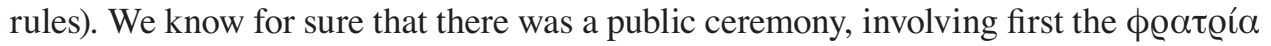
(family group), and then the $\delta \hat{\eta} \mu \circ \varsigma$ (the smallest administrative unit of the Athenian state; less "technically", village), as in the case of a natural offspring. One of the most important reasons for a man to adopt a son was the fear of being left without an heir to look after his death and burial. Reconstructing the rite of affiliation was therefore essential to make the debt of charis, that is fulfil all the rituals that ensure the deceased a peaceful transition to the afterworld, "slip", from the biological father to the adoptive one. By the way, adoption in the ancient world seems to have been a "men's business." 22

It is necessary, then, to broaden the investigation to other cultures, running the risks that are always present in a comparative study, but that can help us to better understand some aspects of Greek thought otherwise unknown to us. ${ }^{23}$ That feeding can create non-biological kinship between an adult (not necessarily a woman) and a child is a common belief. ${ }^{24}$ However, this practice does not usually involve breastfeeding. The only exception in the ancient world comes from Egypt: according to the Egyptian law, if a woman wants to adopt a child, an adolescent or even an adult, she has to offer him her breast to suck. ${ }^{25}$ Evidently, the mythological paradigm is Isis suckling the pharaoh to make him immortal.

The reason for this absence might be simply physiological: a woman can have milk only if she has recently given birth or breastfed a baby. But even if the adoptive mother does have milk, breastfeeding the adopted son is not always considered appropriate. ${ }^{26}$ In a society like ours, where breast milk can easily be replaced by formula, weaning usually occurs within the first year of life, and legal adoption creates a new

\footnotetext{
${ }^{22}$ Scholars have usually studied this topic from a legal (e.g., inheritance, citizenship) and "strategic" point of view (relationships between oikoi, demoi and phratries). Indeed, the sources we have do not allow more than that and Roman law has long influenced this kind of studies. Moreover, as far as Greek law is concerned, information comes mainly from orations, that is full of pathos and not impartial sources. We know, in general, that there were three types of adoption: inter vivos, according to the will expressed in the testament and post mortem. Cf.: RUDHARDT 1962, GOODY 1982, 106ff.; RUBINSTEIN 1993; Rubinstein 2000; CoX 1995, 249-254; LEDUC 1998, 45-60; PATTERSON 1998; BREMMER 1999, 1-20; LINDSAY 2009.

${ }^{23}$ Differences are usually considered as more significant than the similarities within a comparative study, but we should not underestimate the important contribution that analogies can offer as well. A comparative procedure that puts together ancient Greece and other cultures (hopefully closer and familiar to the reader) can be extremely fruitful from a hermeneutic point of view. See CASADIO 2002, 173: "dietro tale idea sussiste una visione antropologica più generale, quella di una fondamentale unità del genere umano, visione che può essere certificata da fatti emergenti da realtà biologiche e psicologiche di base, senza ricorrere a costrutti teologici come l'homo religiosus di Eliade".

${ }^{24}$ In ancient Greek language, the verb trepho, to feed, as in many other languages, is characterized by a wide range of shady meanings: to feed/to breastfeed/to educate/to mould/to rear. Some examples from different cultures: KERLOUEGAN 1968-1969, 101-146; CORBIER 2000, 28; NIELSEN 2000, 249-262; GUERREAU-JALABERT 2000, 263-290; MASSARD-VINCENT 2000, 291-304; JEUDY-BALLINI 1998, 19-44; DASEN 2012, 227-230.

${ }^{25}$ DEONNA 1954, 1161. VAN GENNEP 1981 (or. ed. 1909), 32, generically speaks of real or simulated breastfeeding and simulated birth as typical practices in the rites of adoption.

${ }^{26}$ Some examples of the opposite behaviour in Malaysia JEUDY-BALLINI 1998, 22. It is worth noting that, according to some medical studies, every woman is able to produce some milk, if the breast is properly and regularly stimulated. Today there are adoptive mothers who can breastfeed, by using a breast pump and an instrument called SNS (Supplemental Nursing System), see La Leche League International
} 
family bond that deletes the natural one, issues concerning the survival of the baby during the first years of life and the preservation of blood purity inside the family are no longer perceived as a priority. ${ }^{27}$ In the ancient world, on the contrary, the lack of milk for a new-born involved hiring a wet nurse, with huge consequences for the gens's purity, because of the genetic implications connected with humoral exchanges. For the same reason, in the case of adoption, relatives were preferred.

We also have to take into account another important detail: adoption is a practice that has undergone enormous changes over the centuries. ${ }^{28}$ Today, in the so-called "Western" societies, people are pushed to adoption by the emotional desire of being parents in case of permanent or temporary sterility and by the social need to fill a gap in their own identity. As a consequence, small children are particularly sought after and adoptive parents try to put as much distance as possible between the adoptee and his/her previous identity. From the authorities' point of view, the main issue is the wellness of the child and not the issue of who are the adoptive parents. In the ancient world, the situation was very different: the primary concern was that of the adopter (male) without a natural heir, not that of the adoptee (which is usually an adult, sometimes a child, but very rarely a new-born child). Some aspects, however, remain the same: adoption implies lawful bonds and, usually, emotional involvement; parental duties, such as nutrition and education, pass from the natural parents to the adoptive ones. ${ }^{29}$

Based on this meager, but concrete evidence, it seems reasonable to affirm that the absence of allusions to breastfeeding practices within adoption rites is not surprising, since adoptees usually were not infants and breastfeeding would never be part of a public ceremony. ${ }^{30}$ Considering, however, breast-milk characteristics and its capability to create symbolic and emotional kinship, ${ }^{31}$ it is not unlikely that an allusion to this widespread package of beliefs on breastfeeding would be thought of in the context of a myth that concerns adoption and legitimacy. This allusion might have been gradually "softened", becoming the aition of the Milky Way. A variant of the adult Heracles

website (http://www.1lli.org/lang/ital/italfaq20.html). For breast pumps in antiquity, see GoUREVITCH 1990, 93-99.

${ }^{27}$ In the ancient world, babies were breastfed up to two years, but even beyond. See GouREvITCH 1997, 13-18, 16f.

${ }^{28}$ For instance, cf. GoOdY 1969, 101f.; GOODY 1982, 6-34; CORBIER 2000; LEDUC 1998, 1-15; F.-R. OUELLETTE 1998, 153-176.

${ }^{29}$ CORBIER 2000, 6ff. In the same pages we find an excursus on the term "fosterage". She suggests to traslate it using espressions such as "mise en nourriture", "mise en éducation". Following GoodY 1969, 55-78, Corbier makes a distintion between adoption, which creates a lineage bond, and fosterage, which does not necessarily imply a change of identity. Cf. FINE 1998, 11.

${ }^{30}$ As stated in PEDRUCCI 2015, 27-53, the absence of scenes of breastfeeding women in classical era has to be connected with the concept of aidos, in part related to the emogenesis of human milk, and on the universal sense of "superstition" and fear connected with certain extremely delicate and private phases of woman life (just think to the evil eye).

${ }^{31}$ CORBIER 2000, 7, quoting Paul Veyne, speaks of "vice-famille" around the young aristocratic Roman to help him in his growth. 
would not be in conflict with this hypothesis, but, on the contrary, perfectly consistent, since adoptees were often adult, as we have said. ${ }^{32}$

To come to some conclusions, such an explicit allusion to breastfeeding within a mythical tale involving an "Olympian" goddess cannot just be casual. The possibility of creating kinship via breast milk might suggest its usage for a sort of symbolic, domestic rite of affiliation for children born outside a marriage. The episode of Andromache suckling the bastard children of Hector could be enlightening. The existence of an adoption rite through milk in Egypt, a country that shares many significant beliefs on milk with Greece and Rome, may suggest the idea that the symbolic function of such a gesture was clearly perceived (although the suckling of the pharaoh had a completely different meaning). The breastfeeding of Heracles by Hera may therefore allude to the adoption of the illegitimate son of her husband, in line with the simulation of childbirth. ${ }^{33}$ We are dealing, however, in both cases only with particularly effective allusions, based on a widely shared cultural heritage on breast milk characteristics on the one hand, and on the semantics and symbolic function of nourishment on the other. We cannot assume, in fact, that public ceremonies involving breastfeeding did exist, even though we cannot exclude that in the private sphere, real or symbolic breastfeeding was used to "formalize" the entry of an illegitimate or adopted child into the new family and/or to "ennoble" its blood.

Finally, I would like to go back to the opening question: which was the role of mothers, nurses and other "mother-like" figures in the Greek society? Recent studies underline that nurses adopt a so-called proximal-parenting strategy. ${ }^{34}$

Generally speaking, ancient sources suggest an alloparental care strategy: mothers fostered the mental capacities of their children, while female attendants (nurses and other female relatives) were responsible for the physical care of the infants.

Distal strategy implies an exclusive dyadic relationship between child and caretaker, based on "mentalizing" through eye contact and communication. It is predominant in the "Western" industrial/post-industrial middle-class. It aims toward psychological autonomy. Components of this parenting style were adopted by ancient mothers.

Proximal strategy is an alloparental care strategy with several attachment figures for the child, based on constant body contact but shared attention. It is predominant in traditional subsistence societies. It aims for relational adaption. Components of this parenting style were adopted by female attendants, including wet-nurses.

Even if we started by stating that divine mothering (when it involves "major" goddesses) is essentially kourotrophia, that is, for many reasons more similar to nurs-

${ }^{32}$ We do not know if Etruscans used to adopt adults, but we might assume so, since Greeks and Romans did for similar reasons. In Egypt, as we have seen, the adoption of a child involved breastfeeding, also in case the adoptee was an adult (in a symbolic way), see n. 25.

${ }^{33}$ Contra ROMANi 2004, 94: "se appare incontrovertibile un legame stretto fra l'allattamento di Eracle, la sua apoteosi e la sua rinascita, i due momenti, che si situano ai margini opposti della biografia eroica, non sembrano equivalersi: l'allattamento cioè non assume il medesimo valore simbolico della procedura di rinascita, di adozione messa in atto da Hera”. Cf. CORBIER 2000, 14ff.

${ }^{34}$ Two different parenting styles during the first months of life have been described in the literature: the proximal and the distal style. See KELLER ET AL. 2009, 412-420; RÄUCHLE 2015. 
ing than mothering, if we look to the above-mentioned categories, I would rather say that divine mothering is distal, like that of wealthy ancient mothers. This gives us a clear idea, between other things, of how much the concept of mothering has been changed over centuries.

Indeed, we should ask ourselves if the word "mother" meant the same as it does now, exactly what "mother" means, and what "nurse" means. Wet-nurse's role, in particular, may sound somewhat unfamiliar to our world, supplied as it is with artificial milk. Our "Western" society has developed a new viewpoint regarding motherhood. According to this, mothers should breastfeed and educate their own children; otherwise they will be labelled as selfish, lazy and/or career-oriented. Indeed, the role of today's baby-sitters or nannies is very different from the ancient nurses' one. In our society their work is strictly defined in time and space. Baby-sitters and mothers do not share the same time and space. When the former are in the house, the latter do not turn up, and vice-versa. On the contrary, from ancient sources we learn that mothers and nurses cooperated in children's care, and were often bound together by bonds of friendship and love. Nevertheless, we have to consider the fact that, as usual, we have a very partial overview: our sources reflect only the aristocratic, male point of view. Moreover, concerning this particular case, nurses who had no concern for their nurslings, and nurslings who had no affection for their nurses, have left no commemorative evidence of their attitudes, so that it cannot be simply assumed the nurse's relationship with a child and with its mother was always warm and loving. On the other hand, we do have plenty of evidence of fears and doubts (probably due to jealousy) concerning wet-nurses. Generally speaking, wet-nursing was considered a very humble and controversial job and wet-nurses as shady and suspicious characters. In particular, like prostitutes, they were mothers, whose identity, degree of morality and social functions were affected by their sexuality and the mercenary use of the body implicit in their miserable jobs. Like the midwife (another slave character in ancient societies), the wetnurse had the infant's life in her hands; in folkloric tales, for example, we find many legends of bad nurses, for instance who were associated with the strix, a nocturnal bird who was supposed to fly into houses and suckle blood from sleeping babies. ${ }^{35}$

As a matter of fact, however, in the Greek and Roman worlds the mother was constantly surrounded by many helping figures (attendants and female relatives, like grandmothers, aunts, etc.) in her everyday routine. Moreover, it was not unusual that the mother died in childbirth or was too sick after childbirth to take care of the newborn in person: in those cases, other women (attendants and female relatives, of course, but likely also stepmothers or even neighbors) had to replace the biological mother. In the mare magnum of so-called maternal theory, an articulate reflection on "nursing" is missing. If such a reflection were found, it would be much appreciated.

Giulia Pedrucci

Max Weber Centre for Advanced Cultural and Social Studies

University of Erfurt

${ }^{35}$ MenCACCI 1995, 227-237; Cherubini 2010. Cf. n. 3. 


\section{BIBLIOGRAPHY}

BETTINI, M. 1998: Nascere. Storie di donne, donnole, madri ed eroi. Torino, pp. 3-42. BoISMENU, G. 2009: La vierge sans mère: les métamorphoses d'Athéna adolescente dans l'Odyssée. In Bodiou, L. - Mehl, V. - Oulhen, J. - Prost, F. - Wilgaux, J. (dir.). Chemin faisant. Mythes, cultes et société en Grèce ancienne. Mélanges en l'honneur de Pierre Brulé. Rennes, pp. 261-270.

BONFANTE, L. 1989a: Iconografia delle madri: Etruria e Italia antica. In Rallo, A. (a cura di) : Le donne in Etruria. Roma, pp. 85-106.

Bonfante, L. 1989b: Nursing Mothers in Classical Art. In Koloski, A. O. - Lyons, C. L. (eds): Naked Truths. Women, Sexuality, and Gender in Classical Art and Archaeology. London-New York, pp. 174-196.

BREMMER, J. N. 1999: Fosterage, Kinship and the Circulation of Children in Ancient Greece. Dialogos 6, pp. 1-20.

BRILlante, C. 1992: La paideia di Eracle. In Bonnet, C. - Jourdain-Annequin, C. (dir.): Héraclès. D’une rive à l'autre de la Méditerranée. Bilan et perspectives. Actes de la Table ronde de Rome. Academia Belgica-École française de Rome, 15-16 septembre 1989. Bruxelles, pp. 199-222.

CAPOMACCHIA, A. M. G. 1994: Nutrice di eroi: ruolo e valenza di un personaggio "minore" nella tragedia greca. Studi e materiali di storia delle religioni 18, pp. $11-24$.

CASADIO, G. 2002: Storia della religione greca e storia comparata delle religioni: Brelich (1975/1985) Vernant (19871990), Bremmer (1994/2001). In Bremmer, J.: La religione greca. Cosenza, pp. 157-175.

CheruBini, L. 2010: Strix. La strega nella cultura romana. Torino

CORBIER, M. 2000: Adoptés et nourris. In Corbier, M. (dir.): Adoption et fosterage. Actes d'une table ronde organisée à l'Institut finlandais de Paris les 4 et 5 juin 1993. Paris, pp. 5-41.

Cox, C. A. 1995: The Names of Adoptees: Some Prosopographical Afterthoughts. Zeitschrift für Papyrologie und Epigraphik 107, pp. 249-254.

DANESE, R. M. 1997: Lac humanum fellare. La trasmissione del latte e la linea della generazione. In Raffaelli, R. - Danese, R. M. - Lanciotti, S. (a cura di): Pietas e allattamento filiale. La vicenda, l'exemplum, l'iconografia. Colloquio di Urbino, 2-3 maggio 1996. Urbino, pp. 39-72.

DASEN, V. 2012: Construire sa parenté par la nourriture à Rome. In Dasen, V. - GérardZai, M.-C. (dir.): Nourriture et société de l'Antiquité à nos jours. Gollion, pp. $40-59$.

DeonnA, W. 1954: La légende de Pero et de Micon et l'allaitement symbolique. Latomus 13, pp. 140-166.

FINE, A. 1998: Introduction. In Fine, A. (dir.): Adoptions. Ethnologie des parentés choisies. Paris, pp. 1-15.

Gourevitch, D. 1990: Les tire-lait antiques et la consommation médicale du lait humain. Histoire des Sciences Médicales 24, pp. 93-99. 
GourevitCH, D. 1997: L'alimentation artificielle du petit enfant dans l'antiquité classique. In Alexandre-Bidon, D. - Deschamps, J-P. - Desjardins, M-H. Gourevitch, D. (dir.): Les Biberons du Docteur Dufour. Fécamp, pp. 13-18.

Goody J. 1969: Adoption in Cross-Cultural Perspective. Comparative Studies. Society and History 11, pp. 55-78.

Goody, E. N. 1982: Parenthood and Social Reproduction. Cambridge

GUERREAU-JALABERT, A. 2000: Nutritus/oblatus: parenté et circulation d'enfants au Moyen Âge. In Corbier, M. (dir.): Adoption et fosterage. Actes d'une table ronde organisée à l'Institut finlandais de Paris les 4 et 5 juin 1993. Paris, pp. 263-290.

HADZISTEliou PRICE, T. 1978: Kourotrophos. Cult and Representations of the Greek Nursing Deities. Leiden

JEUDY-BALLINI, M. 1998: Naître par le sang, renaître par la nourriture: en aspect de l'adoption en Océanie. In Fine, A. (dir.): Adoptions. Ethnologie des parentés choisies. Paris, pp. 19-44.

Keller, H. ET AL. 2009: Distal and Proximal Parenting as Alternative Parenting Strategies during Infants' Early Months of Life: A Cross-Cultural Study. International Journal of Behavioral Development 33.5, pp. 412-420.

KeRlouegAN, F. 1968-1969: Essai sur la mise en nourriture et l'éducation dans les pays celtiques d'après le témoignage des textes hagiographiques Latines. Études celtiques 12, pp. 101-146.

LEDUC, C. 1998: L'adoption dans la cite des Athéniens à l'époque classique. In Fine, A. (dir.): Adoptions. Ethnologie des parentés choisies. Paris, pp. 45-60.

LINDSAY, H. 2009: Adoption in the Roman World. Cambridge

LORAUX, N. 1989: Les expériences de Tirésias. Le féminin et l'homme grec. Paris

LORAUX, N. 1991: Il femminile e l'uomo greco. Roma-Bari

MASSARD-VINCENT, J. 2000: Naître chinoise, grandir malaise. In Corbier, M. (dir.): Adoption et fosterage. Actes d'une table ronde organisée à l'Institut finlandais de Paris les 4 et 5 juin 1993. Paris, pp. 291-304.

MENCACCI F. 1995: La balia cattiva: alcune osservazioni sul ruolo della nutrice nel mondo antico. In Raffaelli, R. - Danese, R. M. (a cura di): Vicende e figure femminili in Grecia e a Roma. Atti del Convegno. Pesaro, 28-30 aprile 1994. Ancona, pp. 227-237.

MENCACCI, F. 1996: I fratelli amici. La rappresentazione dei gemelli nella cultura romana. Venezia

NIELSEN, H. S. 2000: Quasi-kin, Quasi-Adoption and the Roman Family. In Corbier, M. (dir.): Adoption et fosterage. Actes d'une table ronde organisée à l'Institut finlandais de Paris les 4 et 5 juin 1993. Paris, pp. 249-262.

Ouellette, F. R. 1998: Les usages contemporains de l'adoption. In Fine, A. (dir.): Adoptions. Ethnologie des parentés choisies. Paris, pp. 153-176.

PATterson, C. B. 1998: The Family in Greek History. Cambridge-London

PEDRUCCI, G. 2013a: L'allattamento nella Grecia di epoca arcaica e classica. Roma

PEDRUCCI, G. 2013b: Sangue mestruale e latte materno: riflessioni e nuove proposte. Intorno all'allattamento nella Grecia antica. Gesnerus 70, pp. 260-291. 
PEDRUCCI, G. 2015: Baliatico, aidos e malocchio: capire l'allattamento nella Grecia di epoca arcaica e classica anche con l'aiuto delle fonti romane. Journal EuGeStA (European network on Gender Studies in Antiquity) 5, pp. 27-53.

PEDRUCCI, G. 2017a: Politeismo e gender studies: riconsiderando la maternità di Hera. In Baglioni, I. (a cura di): Costruzione e Percezione delle Divinità nel Mediterraneo Antico. 10-14 June 2014 - Velletri (Italy), Roma, forthcoming.

PEDRUCCI, G. 2017b: Allaitements 'transgressifs' dans l'antiquité gréco-romaine. In Reboreda Morillo, S. (dir.): Lactación, corpo e sexualidades. Olladas históricas. International workshop, 29-30 October 2015, Ourense (Spain), Paris, forthcoming.

Pirenne-Delforge, V. 2010: Nourricières d'immortalité: Déméter, Héra et autres déesses en pays grec. In Pache-Huber, V. - Dasen, V. (eds): Politics of Child Care in Historical Perspective. From the World of Wet Nurses to the Networks of Family Child Care Providers [Paedagogica Historica 46, special issue], pp. 685-697.

Pirenne-Delforge, V. - Pironti, G. 2009: La féminité des déesses à l'épreuve des épiclèses: le cas d'Héra. In Bodiou, L. - Mehl, V. (dir.): La religion des femmes en Grèce ancienne. Mythes, cultes et société. Rennes, 95-109.

PirenNe-Delforge, V. - PiRONTI, G. 2014: Héra et Zeus à Lesbos: entre poésie lyrique et décret civique. Zeitung für Papyrologie und Epigraphik 191, pp. 27-31.

Pirenne-Delforge, V. - Pironti, G. 2015: Héra et les enfants de Zeus. In Belayche, N. - Pirenne-Delforge, V. (dir.): Fabriquer du divin. Liège, pp. 41-57.

PIRONTI, G. 2013: Des dieux et des déesses: le genre en question dans la représentation du divin en Grèce ancienne. In Boehringer, S. - Sebillotte Cuchet, V. (dir.): Des femmes en action, L'individu et la fonction en Grèce ancienne [special issue of Mètis]. Paris, pp. 155-167.

RÄUCHLE, V. 2015: “For Youth is Impressionable and Plastic.” Parental Care Strategies and Socialization Goals in Classical Athens. American Historical Association, Annual Meeting, New York, 2015 January 2-5.

RENARD, M. 1964: Hercule allaité par Junon. In Renard, M. - Schilling, R. (dir.): Hommages à Jean Bayet. Bruxelles-Berchem, pp. 611-618.

Romani, S. 2004: Nascite speciali. Usi e abusi del modello biologico del parto e della gravidanza nel mondo antico. Alessandria, pp. 87-113.

Rubinstein, L. 1993: Adoption in IV. Century Athens. Copenhague

Rubinstein, L. 2000: Adoption in Classical Athens. In Corbier, M. (dir.): Adoption et fosterage. Actes d'une table ronde organisée à l'Institut finlandais de Paris les 4 et 5 juin 1993. Paris, pp. 46-62.

RUDHARDT, J. 1962: La reconnaissance de la paternité. Sa nature et sa portée dans la société athénienne. Sur un discours de Démosthène. Museum Helveticum 19, pp. 39-64.

VAN GENNEP, A. 1981: I riti di passaggio. Torino

WATson, P. A. 1995: Ancient Stepmothers. Myth, Misogyny \& Reality. Leiden 